\title{
Past 43 year oxalate record: Ürümqi glacier No. 1, Tien Shan, China, and its link with Far East Rongbuk Glacier, Qomolangma (Mount Everest)
}

\author{
LEE Xinging, ${ }^{1,2}$ QIN Dahe, ${ }^{2}$ REN Jiawen, ${ }^{2}$ DUAN KeqIn, ${ }^{2}$ KANG Shichang, ${ }^{2}$ ZHOU Hui ${ }^{1,2}$ \\ ${ }^{1}$ State Key Laboratory of Environmental Geochemistry, Institute of Geochemistry, Chinese Academy of Sciences, Guiyang, Guizhou 550002, China \\ E-mail: lee@lzu.edu.cn \\ ${ }^{2}$ Laboratory of Ice Core and Cold Regions Environment, Cold and Arid Regions Environmental and Engineering Research Institute, Chinese \\ Academy of Sciences, Lanzhou, 730000, China
}

\begin{abstract}
A 43 year oxalate record has been recovered in a $14.08 \mathrm{~m}$ ice core from Ürümqi glacier No. $1\left(43^{\circ} 06^{\prime} \mathrm{N}, 86^{\circ} 49^{\prime} \mathrm{E}\right)$, a mid-latitude glacier at Ürümqi river head, Tien Shan, western China. Averaging $3.6 \pm 9.2 \mathrm{ng} \mathrm{g}^{-1}(\bar{x} \pm 1 \sigma, N=534)$, the oxalate has a background level $<2 \mathrm{ng} \mathrm{g}^{-1}$ with sporadic concentration enhancements. Most of the spikes reach beyond $10 \mathrm{ng} \mathrm{g}^{-1}$ and have durations $<1$ year. The oxalate variation correlates with that in Far East Rongbuk Glacier $\left(27^{\circ} 59^{\prime} \mathrm{N}, 86^{\circ} 55^{\prime} \mathrm{E}\right)$, Qomolangma (Mount Everest), which is located $1600 \mathrm{~km}$ away across the Qinghai-Tibetan Plateau and Taklimakan desert. Although the concentration enhancement in the latter is much higher, and lasts longer, oxalate reaches its highest concentration in both cores at the same time, during winter. The correlation of oxalate records suggests that the two areas may have had the same kind of local sources, but with a much larger $(\mathrm{COO})_{2}{ }^{2-}$ flux in the Qomolangma area, or that they may have had a common source in the Indian subcontinent through the longitudinal atmospheric circulation. The concentration variation in the past 40 years coincides with industrial/economic development in southern Asia, and is mainly due to anthropogenic pollution.
\end{abstract}

\section{INTRODUCTION}

Oxalate $\left((\mathrm{COO})_{2}{ }^{2-}\right)$ is the chief atmospheric dicarboxylic compound (Kawamura and Ikushima, 1993; Kawamura and Usukura, 1993), and is ubiquitous in the troposphere (Schuetzle and others, 1975; Cronn and others, 1977; Grosjean and others, 1978; Norton and others, 1983; Yokouchi and Ambe, 1986; Kawamura and Gagosian, 1987; Kawamura and Kaplan, 1987; Satsumabayashi and others, 1989, 1990; Kawamura and Usukura, 1993). Oxalate may act as a kind of cloud-condensation nucleus, play an important role in geochemical processes in the atmosphere during a long-range transport of inorganic aerosols, and be potentially important to sea-water chemistry by controlling the vertical distribution of oxalic and other organic acids in the surface water (Kawamura and Usukura, 1993). Oxalate presents in the atmosphere mainly in the form of particulates (Norton and others, 1983; Kawamura and Kaplan, 1987; Andreae and others, 1988; Ludwig and Klemm, 1988; Sempere and Kawamura, 1994; Matsumoto and others, 1998; Baboukas and others, 2000), while a fraction of it dissolves in cloud droplets (Norton and others, 1983; Kawamura and others, 1985; Sempere and Kawamura, 1994), and an even smaller fraction appears in gaseous form (Norton and others, 1983; Ludwig and Klemm, 1988; Lefer and others, 1994; Baboukas and others, 2000). Although not certain at present, several sources have been found contributing to its atmospheric concentration. Provenance for direct emissions includes forest fires (Andreae and others, 1988; Lefer and others, 1994; Legrand and de Angelis 1995, 1996), motor exhaust and soil release
(Kawamura and Kaplan, 1987; Grosjean, 1989). Atmospheric reactions of anthropogenic hydrocarbons (Grosjean and others, 1978; Grosjean and Friedlander, 1980; Hatakeyama and others, 1985, 1987) and biogenic unsaturated fatty acids (Yokouchi and Ambe, 1986; Kawamura and Gagosian, 1987) are secondary sources. More recently, it has been suggested that volcanic eruptions also emit oxalate to the air (Baboukas and others, 2000).

Past atmospheric variations of oxalate can be retrieved in ice cores from polar areas or mid- and low-latitude glaciers, given a good knowledge of the relation between the composition of snow and that of the atmosphere. Unfortunately, there have been only a few studies involving the record in polar ice cores (Kawamura and Yasui, 1991; Legrand and others, 1992; Legrand and de Angelis, 1995, 1996), and even research on mid- and low-latitude regions is rare (Kang and others, 2001). Recent studies indicated $(\mathrm{COO})_{2}{ }^{2-}$ in Greenland ice cores over the past 200 years averaged about $0.4 \mathrm{ng} \mathrm{g}^{-1}$, with perturbations probably reflecting biomass-burning events in the high northern latitudes (Legrand and de Angelis, 1995, 1996). By contrast, in Far East Rongbuk Glacier (FER Glacier) $\left(27^{\circ} 59^{\prime} \mathrm{N}\right.$, $86^{\circ} 55^{\prime} \mathrm{E}$ ), which is located about $13 \mathrm{~km}$ north of the peak of Qomolangma (Mount Everest), $(\mathrm{COO})_{2}{ }^{2-}$ in the past 180 years averaged $13.7 \mathrm{ng} \mathrm{g}^{-1}$, with the highest values occurring in the 1960s. The concentration increase from the beginning of the 20th century has been attributed to industrial pollution (Kang and others, 2001).

In this paper, we investigate variations of the past 43 year oxalate record in an ice core from Ürümqi glacier 
No. 1 (UG1), a mid-latitude glacier in China, and compare the record with that of FER Glacier. We examine the possible implications for the oxalate source as well as the longitudinal atmospheric interaction between the Tien Shan and Qomolangma areas.

\section{ÜRÜMQI GLACIER NO. 1 AND THE IGE CORE}

Located at $43^{\circ} 06^{\prime} \mathrm{N}, 86^{\circ} 49^{\prime} \mathrm{E}$ in central Eurasia, UG1 is a valley glacier at Ürümqi river head, Xinjiang Autonomous Region, China. It is composed of east and west branches and occupies a total area of about $1.84 \mathrm{~km}^{2}$ (Liu and others, 1991) (Fig. 1). The equilibrium-line altitude averaged $3976 \mathrm{~m}$ a.s.l. during 1979-89, and has risen to $>4000 \mathrm{~m}$ a.s.l. in recent years (Chinese Academy of Sciences, 1979-98). The mean annual precipitation at $4050 \mathrm{~m}$ a.s.l. in the accumulation area of the east branch is $645.8 \mathrm{~mm} \mathrm{a}^{-1}$ w.e. (Wang and Zhang, 1985; Yang and others, 1988). The May-September period accounts for $88 \%$ of the annual precipitation (Wang and Zhang, 1985; Yang and others, 1992; Zhang and others, 1994). There are only a few cities or towns within $100 \mathrm{~km}$ of the glacier. The nearest town, Houxia, is located $50 \mathrm{~km}$ away in the river valley, and has a steel works and a cement plant which have been built since 1958. To the northeast of UGl, $105 \mathrm{~km}$ away, lies Ürümqi, the capital city of Xinjiang.

The ice core studied here is $14.08 \mathrm{~m}$ long and was retrieved in October 1998 at $4040 \mathrm{~m}$ a.s.l. in the superimposed-ice zone of the east branch of UGl, close to the monitored point $\mathrm{H}_{2}{ }^{\prime}$ at $4042 \mathrm{~m}$ a.s.l. (Fig. 1). It is composed of clear, dense ice with scarce bubbles, which formed in the superimposed-ice zone,

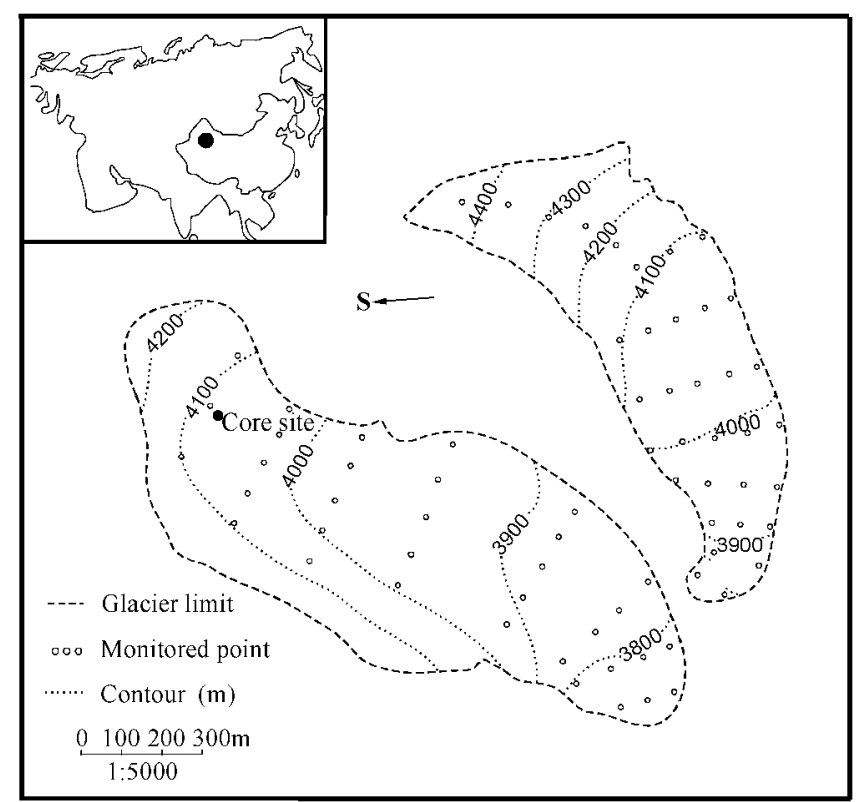

Fig. 1. UG1, with its location represented by the black dot in the inset map of Eurasia. The drilling site is located near the monitored point $\mathrm{H}_{2}^{\prime}$ at the east branch of the glacier.

and opaque, bubbly ice with spherical bubbles $1-2 \mathrm{~mm}$ in diameter, which formed in the percolation zone, as well as dust layers, of which two strong ones occurred at 0-6 and $1300-1317 \mathrm{~cm}$, respectively. The superimposed ice accounts for $80-90 \%$ of the core, whereas the bubbly ice and the dust

\section{Calendar Year}

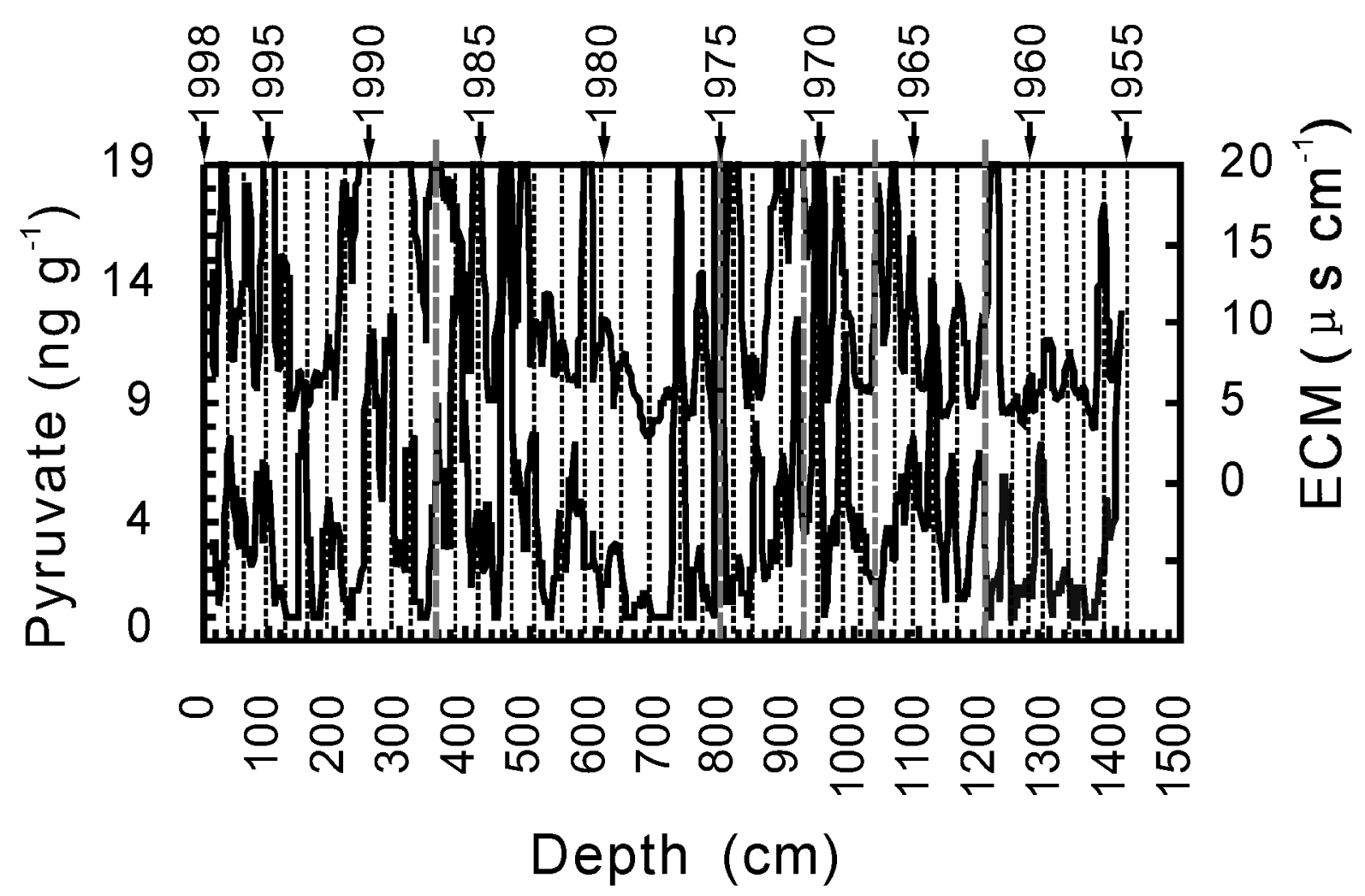

Fig. 2. Cross-dating for the whole ice core by ECM and pyruvate from the bottom (1955) to the surface. Solid straight lines protruding from the upper boundary of the graph indicate the reference levels from $\delta^{18} \mathrm{O}$ and $\beta$ activity, and represent from right to left 1962, 1966, 1970, 1976 and 1986. 


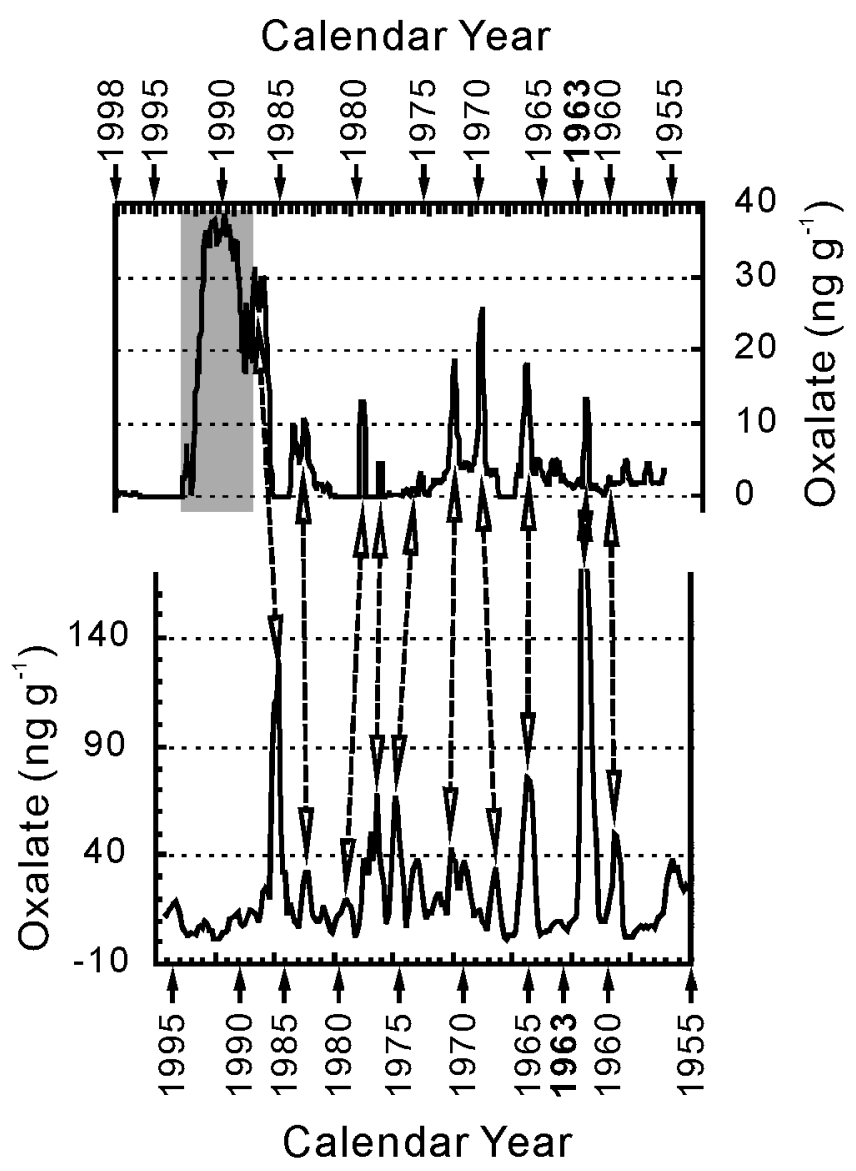

Fig. 3. Comparison of oxalate variation in the UG1 ice core ( upper graph) with the record from FER Glacier. Both curves result from the six-point running mean of their data. The strong shaded peak in UG1 results from post-depositional effect of the crack.

layers total $10-20 \%$. In the upper part of the ice core, from 138 to $386 \mathrm{~cm}$, there is a nearly vertical crack. The ice within $2-3 \mathrm{~cm}$ of the fracture differs from the adjacent ice layers in its transparency and uniformly elongated bubbles, with long axes perpendicular to the fracture plane. It was formed from surface meltwater during the development of the crack (Lee and others, 2002a).

The core was cross-dated by $\delta^{18} \mathrm{O}, \beta$ activity, and variations of pyruvate and electric conductivity measurement (ECM). Temperatures from June to August control the $\delta^{18} \mathrm{O}$ in UG1 (Hou and others, 2000), so we dated the core first by comparing $\delta^{18} \mathrm{O}$ with the temperature in the area. This provides four reference dates: 1962, 1966, 1970 and 1976. Measurements of $\beta$ activity provide events in 1963, 1967, 1976, 1980 and 1986, corresponding to the known nuclear fallout events in the Northern Hemisphere and western China and to the Chernobyl nuclear accident. Dating via these two series differs by about 1 year. The whole core was dated by crosscounting peaks of ECM and pyruvate while consulting the reference dates from $\delta^{18} \mathrm{O}$ and $\beta$ activity. It covers a period of 43 years from 1955 to 1998 with an uncertainty of about 1 year (Fig. 2).

\section{ANALYTIGAL TEGHNIQUES}

The ice core was sectioned every $2 \mathrm{~cm}$ in the laboratory, and only the central part was used for analysis. In the cracked section, however, the analytical samples were selected to avoid the fracture as much as possible. In order to avoid the outer $1 \mathrm{~cm}$ of the core that is susceptible to drilling contamination (Legrand and others, 1993), the sampling was compromised by including parts of the transparent ice. The samples were kept frozen in glass vials with airtight covers until analysis.

Oxalate in 662 samples was analyzed by a DX-300 ion chromatograph with AS4A and ASRS-II columns. Gradient elution by $\mathrm{Na}_{2} \mathrm{~B}_{4} \mathrm{O}_{7}$ and chemical suppression mode with $25 \mathrm{mM} \mathrm{H}_{2} \mathrm{SO}_{4}$ as well as a preconcentration technique were used for the measurement. A relative uncertainty of $4 \%$ for oxalate was obtained with a $2 \mathrm{~mL}$ sample and calibrated by the AccuIon ${ }^{(\times)}$Reference Standard IC-OXALIX-1. For more details of the analysis, see Lee and others (2002b).

\section{RESULTS AND COMPARISON}

Oxalate is a minor organic compound compared with acetate and formate, the light carboxylic acids which in the ice core average $392.3 \pm 390.8 \mathrm{ng} \mathrm{g}^{-1}$ and $102.8 \pm 147.3 \mathrm{ng} \mathrm{g}^{-1}(\bar{x} \pm 1 \sigma$, $N=662$ ), respectively (Lee and others, 2001). Although the background level is about $1-2 \mathrm{ng} \mathrm{g}^{-1}$, oxalate concentration in parts of the ice core is below the detection limit (see upper graph in Fig. 3). If the concentration in the crack, where $(\mathrm{COO})_{2}{ }^{2-}$ is significantly enhanced (shaded area in the upper graph of Fig. 3) due to the cracking effect (Lee and others, $2002 \mathrm{a}$ ), is not taken into account, the mean concentration of oxalate in the past 43 years is $3.6 \pm 9.2 \mathrm{ng} \mathrm{g}^{-1} \quad(N=534)$, nearly 10 times higher than in the Greenland ice cores (Legrand and de Angelis, 1995). In the FER Glacier ice core, however, $(\mathrm{COO})_{2}{ }^{2-}$ averages $23.7 \pm 41.1 \mathrm{ng} \mathrm{g}^{-1}(N=216)$ from 1955 to 1996 (Kang and others, 2001), about 6 times higher than the mean concentration in UGl.

Despite its low average concentration, oxalate does have spikes, most of which reach 10-30 times higher than the background level and cover a period of approximately 1 year. Striking peaks from right to left (Fig. 3) correspond to 1962, 1966, 1970, 1973, 1978, 1979, 1983 and 1986. These spikes are not necessarily related to the percolation ice layers nor to the dust ones. The two strong dust layers, for instance, are both free of the oxalate peaks. Therefore the oxalate increases are independent of the constitution of the ice, as opposed to the effect of the cracking.

Kang (1999) dated the FER ice core using $\beta$ activity, $\delta^{18} \mathrm{O}$ and profiles of $\mathrm{Ca}^{2+}$ and $\mathrm{SO}_{4}{ }^{2-}$. The reference dates 1954 and 1963 are at 9.4 and $6.9 \mathrm{~m}$, respectively. The years from 1955 to the core surface in 1996 stretch a length of $9 \mathrm{~m}$ (Kang, 1999). Based on the dating, the spikes in UGl match those in FER Glacier during the past 40 years: most of the spikes in one glacier have counterparts in the other, especially allowing for dating errors for the two cores (Fig. 3). Note, however, that the strong shaded peak in UGl is caused by the crack, and thus has no corresponding peak in FER Glacier. On the other hand, peaks in FER Glacier are much higher than, although not strictly proportional to, their counterparts in UGl, which probably indicates a greater increase of oxalate in the atmosphere over FER Glacier. Peaks in FER Glacier are also wider than those in UGl. The spatial interval for analytical samples in the FER core is $4 \mathrm{~cm}$. Given the glacier's mean annual accumulation of $22 \mathrm{~cm} \mathrm{a}^{-1}$ ice equivalent in the past 40 years, the average sample resolution is 5.5 samples per year compared to 16.8 samples per year for UGl. The lower resolution of sample selection in the FER core would certainly widen the peaks. The wider peaks in FER Glacier may also be 
Table 1. Mean oxalate concentration (in $n g g^{-1}$ ) recorded in UG1 and FER Glacier during periods 1955-60, 1960-80, 1980-90 and 1990-96

1955-60 1960-80 1980-90 1990-96

Ürümqi glacier No. 1

FER Glacier

2.5

21.2

5.0
27.4

3.0

$<1.0$

related to the possibility that the concentration enhancement in the atmosphere dominates for a longer time over the Qomolangma area, whereas it both increases and decreases quickly and lasts a shorter time in the Tien Shan. The relative importance of the two possibilities cannot be assessed here because insufficient data are available.

The oxalate records in the two areas can be divided into four periods in terms of their concentration during the past 40 years (Table 1). UG1 recorded low levels of oxalate in the latter half of the $1950 \mathrm{~s}$, with a mean concentration of $2.5 \mathrm{ng} \mathrm{g}^{-1}$, whereas the $1960 \mathrm{~s}$ and 1970s saw the highest average concentration of $5.0 \mathrm{ng} \mathrm{g}^{-1}$, with the peaks occurring mainly in the latter period. Oxalate levels in the 1980s are close to those in the later $1950 \mathrm{~s}$, with an average concentration of $3.0 \mathrm{ng} \mathrm{g}^{-1}$ resulting chiefly from the spike in 1986. The 1990s have the lowest concentration, which is below the detection limit for most samples. As in the UGl core, oxalate in the FER ice core also has the highest concentration in 1960-80, and the lowest concentration in the 1990s, with a middling concentration in 1955-60 and the 1980s (see Table 1). The average concentration of $24 \mathrm{ng} \mathrm{g}^{-1}$ in the $1980 \mathrm{~s}$ is also mainly due to the 1986 peak.

\section{DISGUSSION}

The correlation of oxalate records between UG1 and FER Glacier suggests that $(\mathrm{COO})_{2}{ }^{2-}$ over the two areas may have varied synchronously or had a common source.

The co-variation of $(\mathrm{COO})_{2}{ }^{2-}$ may be caused by local sources which have been in phase with each other in releasing oxalate to the atmosphere. The oxalate flux, however, differs, being much larger at FER Glacier than at UGl. It is probably this difference that causes oxalate peaks to be stronger in FER Glacier than in UGl. The timing of the peaks, on the other hand, is the same, which suggests that the two areas may have had the same kind of local sources.

The other plausible explanation is that the two areas have

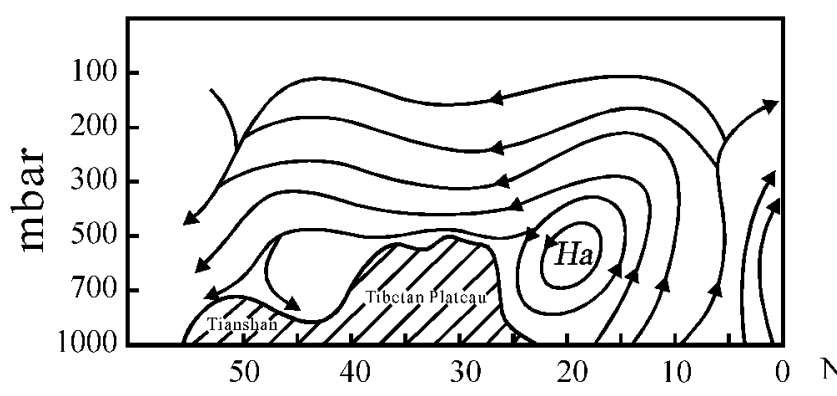

Fig. 4. An example of longitudinal air movement along $90^{\circ} \mathrm{E}$ on 1 fune 1979, demonstrating the direct atmospheric connection between the Tien Shan and Qomolangma areas. Ha stands for Hadley circulation. Modified from Zhang and others (1984). shared the same source, and the Indian subcontinent may be the main provenance for both records. This scenario is based on the longitudinal atmospheric circulation linking the two areas. Although some meteorologists doubt the linkage (e.g. personal communication from Qian Zhengan, 2000), airmass exchange by the circulation has been observed. Schematically shown in Figure 4 is an example of the circulation along $90^{\circ} \mathrm{E}$ on 1 June 1979 (Zhang and others, 1984). To the south of the Qinghai-Tibetan Plateau, Hadley circulation dominates. The upwelling air mass develops from south of $15^{\circ} \mathrm{N}$ and turns north in the upper level of the troposphere. It crosses over the plateau and then descends around $50^{\circ} \mathrm{N}$ near the Tien Shan. This longitudinal circulation is prone to occur in winter and spring when the Indian monsoonal circulation system is not active, and when oxalate has higher concentration in precipitation over UGl, as discussed below. The longitudinal circulation acts as a conveyer for chemical species from the tropical area to reach the mid-latitudes. In a recent study, it was found that oxalate can be transported over a long distance due to its existence in fine particles (Matsumoto and others, 1998). This indicates the feasibility of $(\mathrm{COO})_{2}{ }^{2-}$ being transported from the Indian subcontinent to the Tien Shan. The gradual oxalate depletion of the air mass due to deposition in the long transportation could result in the lower oxalate in UG1.

The geographical contrasts make a chemical connection between the two sectors worthy of attention. UGl is located in the central part of the Eurasian continent. It is surrounded by vast areas of deserts and the Gobi, whereas FER Glacier lies below $30^{\circ} \mathrm{N}$. The glaciers are separated longitudinally by $>1600 \mathrm{~km}$ in very different geographic environments. They also differ considerably in height. FER Glacier protrudes two-thirds of the way through the troposphere, and the drilling site is $2460 \mathrm{~m}$ higher than that at UG1. Additionally, the sites differ in the regional prevailing atmospheric circulation systems (Dai, 1990). However, the oxalate-record correlation suggests that atmospheric connection between the two areas is stronger than previously thought.

Unfortunately, our limited dataset does not allow a more definitive explanation for the correlation. The primary source of oxalate, however, can be pinpointed as anthropogenic as follows. In contrast to the Greenland ice-core record, where spikes of oxalate result from boreal forest fires (Legrand and de Angelis, 1995, 1996), the concentration enhancements in UGl are unlikely to be from forest fires, since no forest fires intense enough to affect the surrounding atmosphere have been observed in either western China or the Indian subcontinent corresponding to the years when the spikes occurred. Biogenic emission is not the main source either. Because the coverage of vegetation in western China is very limited, emission from vegetation would not cause significant changes in atmospheric concentration. As mentioned above, precipitation in seasons other than summer over the UG1 area accounts for only about $22 \%$ of the whole year, which means a very low frequency of precipitation in these seasons (especially winter). A recent study showed that oxalate tends to concentrate in precipitation events of lower frequency, partly because a high precipitation rate keeps oxalate low in the atmosphere by scavenging it frequently, causing a low oxalate concentration for individual precipitation events (Sempere and Kawamura, 1994). This mechanism explains the oxalate enhancements in UGl during winter. Since this is not the growth season, the oxalate spikes cannot be mainly the result of vegetational 
emission from the Indian subcontinent, nor are they likely to be due to emission of soil. The primary provenance appears to be directly or indirectly from anthropogenic emission. This is partly supported by evidence from the FER ice core that the mean concentration of oxalate is $2-3$ times higher in the 20th century than in the 19th century (Kang and others, 2001). For the synchronism, pollution from Ürümqi and Houxia and from the densely populated Indian subcontinent would act, respectively, as sources for each ice-core record. On the other hand, if the two areas have shared the same source, they both result primarily from anthropogenic emissions in the Indian subcontinent. In either case, the oxalate variations coincide with recent industrial/economic development in southern Asia. The period of relatively low concentration before 1960 through to the highest concentration in the 1960s and 1970s corresponds to the process of regional economic growth, while the decline in the 1980s and then eventually to the background in the 1990s may reflect the measures prompted by governmental and industrial awareness of the environmental problem during the past 20 years.

\section{GONCLUSIONS}

The past 43 year oxalate record in an ice core from UG1 shows that oxalate is a minor carboxylic species with a mean concentration of $3.6 \pm 9.2 \mathrm{ng} \mathrm{g}^{-1} \quad(\bar{x} \pm 1 \sigma, N=534)$. The background level is $<2 \mathrm{ng} \mathrm{g}^{-1}$, with some samples having a concentration below the detection limit. The record is nearly 10 times higher than in Greenland ice cores, but about 6 times lower than in FER Glacier.

Superimposed on the background level of the UGl record are sporadic oxalate enhancements, which correlate with those in FER Glacier in the past 40 years. This suggests that the two areas may have had the same kind of local sources, with the source strength for FER Glacier much larger than for UGl, or, alternatively, a common source from the Indian subcontinent via the longitudinal circulation of atmosphere. In either case, the oxalate record coincides with industrial/ economic development in southern Asia, and is directly or indirectly due to anthropogenic emissions.

\section{ACKNOWLEDGEMENTS}

We would like to thank Hou Shugui, Xiao Cunde, Tian Lide and He Yuanqing of CAREERI for helpful discussions, and Qian Zhengan and Li Peiji of the same Institute for their reviews of an initial draft of this paper. We acknowledge valuable suggestions and editorial assistance from $T$. van Ommen, and comments from two anonymous reviewers that helped improve the clarity and accuracy of the paper. This study was financed by the National Natural Science Foundation of China (grant Nos. 40073035 and 49871022), the Chinese Academy of Sciences (grant No. KZ951-Al402-03), the Tien Shan Glaciological Station and the Chinese postdoctoral research foundation.

\section{REFERENGES}

Andreae, M. O. and 13 others. 1988. Biomass-burning emission and associated haze layers over Amazonia. 7. Geophys. Res., 93(D2), 1509-1527.

Baboukas, E. D., M. Kanakidou and N. Mihalopoulos. 2000. Carboxylic acids in gas and particulate phase above the Atlantic Ocean. 7. Geophys. Res., 105(D11), 14,459-14,471.
Chinese Academy of Sciences. 1979-98. [Annual reports of Tien Shan glaciological station.7 Vol. 1-10. Lanzhou, Chinese Academy of Sciences. Lanzhou Institute of Glaciology and Geocryology. [In Chinese.]

Cronn, D. R., R.J. Charlson, R. L. Knight, R. L. Crittenden and B. R. Appel. 1977. A survey of the molecular nature of primary and secondary components of particles in urban air by high-resolution mass spectroscopy. Atmos. Environ., 11, 929-937.

Dai Jiaxi. 1990. [Climate of Qinghai-Tibetan Plateau.] In Dai Jiaxi, ed [Climate on the Tibetan Plateau]. Beijing, Meteorological Press, 51-196. [In Chinese.]

Grosjean, D. 1989. Organic acids in southern California air: ambient concentrations, mobile source emissions, in situ formation and removal processes. Environ. Sci. Technol., 23, 1506-1514.

Grosjean, D. and S. K. Friedlander. 1980. Formation of organic aerosols from cyclic olefins and diolefins. Adv. Environ. Sci. Tech., 9, 435-473.

Grosjean, D., K. van Cauwenberghe, J. P. Scvhmid, P. E. Kelley and J. N. Pitts, Jr. 1978. Identification of $\mathrm{C}_{3}-\mathrm{C}_{10}$ aliphatic dicarboxylic acids in airborne particulate matter. Environ. Sci. Technol., 12, 313-317.

Hatakeyama, S., T. Tanonaka, J. Weng, H. Bandow, H. Takagi and H Akimoto. 1985. Ozone-cyclohexene reaction in air: quantitative analysis of particulate products and the reaction mechanism. Environ. Sci. Technol., 19, 935-942.

Hatakeyama, S., M. Ohno, J. Weng, H. Takagi and H. Akimoto. 1987. Mechanism for the formation of gaseous and particulate products from ozone-cycloalkene reactions in air. Environ. Sci. Technol., 21, 52-57.

Hou Shugui, Qin Dahe, C. P. Wake, P. A. Mayewski, Ren Jiawen and Yang Qinzhao. 2000. Climatological significance of an ice core net-accumulation record at Mt. Qomolangma (Everest). [Chin. Sci. Bull.], 45(3), 259-264.

Kang Shichang. 1999. [A study of the present processes in the snow/ice and the climatic and environmental records in the northern slope of the middle Himalayas.] (Ph.D. thesis, Lanzhou Institute of Glaciology and Geocryology.) [In Chinese, with English abstract.]

Kang Shichang, Qin Dahe, P. A. Mayewski and C. P. Wake. 2001. Correspondence. Recent 180 years oxalate $\left(\mathrm{C}_{2} \mathrm{O}_{4}{ }^{2-}\right)$ records recovered from the Mount Everest ice core: some environmental implications. f. Glaciol., 47(156), 155-156.

Kawamura, K. and R. B. Gagosian. 1987. Implication of $\omega$-oxocarboxylic acids in the remote marine atmosphere for photo-oxidation of unsaturated fatty acids. Nature, 325, 330-332.

Kawamura, K. and K. Ikushima. 1993. Seasonal changes in the distribution of dicarboxylic acids in the urban atmosphere. Environ. Sci. Technol., 27, 2227-2235.

Kawamura, K. and I. R. Kaplan. 1987. Motor exhaustion emissions as primary source for dicarboxylic acids in Los Angeles ambient air. Environ. Sci. Technol., 21, 105-110.

Kawamura, K. and K. Usukura. 1993. Distribution of low weight dicarboxylic acids in the North Pacific aerosol samples. Fournal of Oceanography, 49, 271-283

Kawamura, K. and O. Yasui. 1991. Organic acids and aldehydes in the ice samples from Site-J, Greenland. Bull. Glacier Res. 9, 59-63.

Kawamura, K., L.-L. Ng and I. R. Kaplan. 1985. Determination of organic acids $\left(\mathrm{C}_{1}-\mathrm{C}_{10}\right)$ in the atmosphere, motor exhausts, and engine oils. Environ. Sci. Technol., 19(11), 1082-1086.

Lee Xinqing, Qin Dahe and Zhou Hui. 2000. [Determination of organic acids in snow and ice from mountain glaciers.] 7. Glaciol. Geocryol., 22(3), 270-277. [In Chinese with English abstract.]

Lee Xinqing, Qin Dahe, Ren Jiawen and Zhou Hui. 2001. Organic acids: differences in ice core records between Glacier 1, Tien Shan, China, and the polar areas. [Chin. Sci. Bull.], 46(1), 80-82.

Lee Xinqing, Qin Dahe, Hou Shugui, Ren Jiawen, Duan Keqin and Zhou Hui. 2002a. Changes in chemical and isotopic properties near infiltrated cracks in an ice core from Ürümqi glacier No. 1, Tien Shan, China. Ann. Glaciol., 35 (see paper in this volume).

Lee Xinqing, Qin Dahe, Jiang Guibin and Zhou Hui. 2002b. Determination of light carboxylic acids in snow and ice from mountain glaciers. Cold Reg. Sci. Technol., 34(2), 127-134.

Lefer, B. L. and 13 others. 1994. Enhancement of acidic gases in biomass-burning impacted air masses over Canada. F. Geophys. Res., 99(D1), 1721-1737.

Legrand, M. and M. de Angelis. 1995. Origins and variations of light carboxylic acids in polar precipitation. 7. Geophys. Res., 100(D1), 1445-1462.

Legrand, M. and M. de Angelis. 1996. Light carboxylic acids in Greenland ice: a record of past forest fires and vegetationemissions from the boreal zone. 7. Geophys. Res., 101(D2), 4129-4145.

Legrand, M., M. de Angelis, T. Staffelbach, A. Neftel and B. Stauffer. 1992. Large perturbations of ammonium and organic acids content in the Summit-Greenland ice core: fingerprint from forest fires? Geophys. Res. Lett., 19(5), 473-475.

Legrand, M., M. de Angelis and F. Maupetit. 1993. Field investigation of major and minor ions along Summit (central Greenland) ice cores by 
ion chromatography. F. Chromatogr., 640(1-2), 251-258.

Liu Chaohai and 8 others. 1991. [Handbook of Tien Shan glaciological station.] Lanzhou, Gansu Science and Technology Press. [In Chinese.]

Ludwig, J. and O. Klemm. 1988. Organic acids in different size classes of atmospheric particulate material. Tellus, 40B, 340-347.

Matsumoto, K., I. Nagao, H. Tanaka, H. Miyaji, T. Iida and Y. Ikebe. 1998. Seasonal characteristics of organic and inorganic species and their size distributions in atmospheric aerosols over the northwest Pacific Ocean. Atmos. Environ., 32(11), 1931-1946.

Norton, R. B., J. M. Roberts and B. J. Huebert. 1983. Tropospheric oxalate. Geophys. Res. Lett., $10(7), 517-520$.

Satsumabayashi, H., H. Kurita, Y. Yokouchi and H. Ueda. 1989. Mon- and di-carboxylic acids under long-range transport of air pollution in central Japan. Tellus, 14B, 219-229.

Satsumabayashi, H., H. Kurita, Y. Yokouchi and H. Ueda. 1990. Photochemical formation of particulate dicarboxylic acids under long-range transport in centralJapan. Atmos. Environ., 24(6), 1443-1450.

Schuetzle, D., D. Cronn and R. L. Crittenden. 1975. Molecular composition of secondary aerosol and its possible origin. Environ. Sci. Technol., 9, 838-845.

Sempere, R. and K. Kawamura. 1994. Comparative distributuions of dicarboxylic acids and related polar compounds in snow, rain and aerosols from urban atmosphere. Atmos. Environ., 28(3), 449-459.

Wang Dehui and Zhang Peiyuan. 1985. [On the valley climate of Ürümqi River in the Tien Shan mountains.] f. Glaciol. Geocryol., 7 (3), 239-248. [In Chinese with English summary.]

Yang Daqing, Jiang Tong, Zhang Yinsheng and Kang Ersi. 1988. [Analysis and correction of errors in precipitation measurement at the head of Ürümqi River, Tien Shan.] 7. Glaciol. Geocryol., 10(4), 384-399. [In Chinese with English abstract.]

Yang Daqing, Kang Ersi and F. Blumer. 1992. [Characteristics of precipitation in the source area of the Ürümqi River Basin.] F. Glaciol. Geocryol., 14(3), 258-266. [In Chinese with English summary.]

Yokouchi, Y. and Y. Ambe. 1986. Characterization of polar organics in airborne particulate matter. Atmos. Environ., 20, 1727-1734.

Zhang Jinshi, Peng Ruihua, Wang Dali and Zhou Shuhai. 1984. [Seasonal variation of atmospheric circulation in the Northern Hemisphere in early summer of 1979.] In [Collection of scientific experiment on meteorology of QinghaiTibetan Plateau (II) ]. Beijing, Science Press, 121-131. [In Chinese.]

Zhang Yinsheng, Ersi Kang and Liu Chaohai. 1994. [Climatic features of Tien Shan Ürümqi River Valley.] f. Glaciol. Geocryol., 16(4), 333-341. [In Chinese with English summary.] 